\title{
Erratum to: Critical zone properties control the fate of nitrogen during experimental rainfall in montane forests of the Colorado Front Range
}

\author{
Eve-Lyn S. Hinckley - Brian A. Ebel - Rebecca T. Barnes • \\ Sheila F. Murphy $\cdot$ Suzanne P. Anderson
}

Published online: 10 July 2017

(C) Springer International Publishing AG 2017

\section{Erratum to: Biogeochemistry (2017) 132:213-231 DOI 10.1007/s10533-017-0299-8}

In the PDF and printed version of this article Eq. (1) on p. 219 contains an error: the terms of the denominator appear twice. Eq. (1) should read as follows:

$$
\begin{aligned}
{ }^{15} \mathrm{~N}_{\text {rec }}= & {\left[m_{\text {pool }}\left(\text { at. } \%{ }^{15} \mathrm{~N}_{\text {pool }}-\text { at. } \%{ }^{15} \mathrm{~N}_{\text {ref }}\right)\right] } \\
& /\left(\text { at. } \%{ }^{15} \mathrm{~N}_{\text {tracer }}-\text { at. } \%{ }^{15} \mathrm{~N}_{\text {ref }}\right)
\end{aligned}
$$

The online version of the original article can be found under doi:10.1007/s10533-017-0299-8.

\section{E.-L. S. Hinckley $(\bowtie)$}

Environmental Studies Program, University of Colorado, 4001 Discovery Dr, Boulder, CO 80303, USA

e-mail: eve.hinckley@colorado.edu

\section{E.-L. S. Hinckley · S. P. Anderson}

Institute of Arctic and Alpine Research, 4001 Discovery Dr, Boulder, CO 80303, USA

B. A. Ebel

National Research Program, United States Geological

Survey, Lakewood, CO 80225, USA
The online version of the article is correct.

The publishers apologize for the inconvenience caused.
R. T. Barnes

Colorado College, 14 E. Cache La Poudre,

Colorado Springs, CO 80903, USA

\section{S. F. Murphy}

United States Geological Survey, 3215 Marine St, Ste.

E-127, Boulder, CO 80303, USA

\section{S. P. Anderson}

Department of Geography, 260 UCB, University of

Colorado, Boulder, CO 80309, USA 